\title{
ASSESSMENT OF INFLUENCE OF MANAGEMENT TRANSFORMATIONS AND RISK FOR TOURISM BUSINESS
}

\author{
Dalė Dzemydiené1, Mohamed Hamdy-Elmeselhy-Aly Ragab ${ }^{2}$ \\ Department of Business Technologies and Entrepreneurship, Faculty of Business Management, \\ Vilnius Gediminas Technical University, Sauletekio av. 11, LT-10223, Vilnius, Lithuania \\ E-mails: ${ }^{1} d a l e . d z e m y d i e n e @ v g t u . l t$ (corresponding author); \\ ${ }^{2}$ mohamed-hamdy-elmeselhy-aly.ragab@stud.vgtu.lt
}

Received 18 March 2020; accepted 04 May 2020

\begin{abstract}
The reality of development of tourism business is faced with problems of unsuspected events and unsustainable management issues. This research explores the need to evaluate the types of risk in tourism business sector. The aim of this research is to analyze the situations of local and global business in the area of management transformations in tourism sector. For empirical evaluation of situation the statistical data are analyzed in case study of Egypt tourism sector during the period of 10 years. The models are proposed for application, such as environmentally sustainable tourism planning, adapting roles of tourism stakeholders, integration of private investors, action plans. The results demonstrate the lack of significant sustainable development practices under the conditions of unsuspectability and show interest in this area by needs for further contribution involving triple bottom line of objectives. The some factors are found as risk of political changes, lack of skills, finance etc.
\end{abstract}

Keywords: tourism business management, sustainable development, multi-objective decision support, risk evaluation.

JEL Classification: M16, Z32, L52.

\section{Introduction}

Some important aspects of influences of critical managerial and destructional transformations (as revolution, pandemia, unsustainable political decisions) for development of tourism business are analysed in this research. Unsustainability concerns some types of risk which is influencing by many factors, i.e. business performance related with environmental awareness, unrespectable political influences, community responsibility, performance barriers, epidemiological crisis, and other issues. The main attention is provided for special risky situations in the tourism busines sector. The factors are found to be prohibiting for the effective embedment of sustainable development within companies and hence cause an under-performance in this regard. By comparative analysis of statistical data the risk and destruction of business by revolution in Egypt is shown. Some comparative analysis is made by evalution of situation in business sector of Egypt and other countries.

The World Commission on Environment and Development's much quoted definition of sustainable development is "Sustainable development seeks to meet the needs and aspirations of the present without compromising the ability to meet those of the future" (Transforming our world...,
2015). Sustainability issues that arise outside the business world are broadly natural and social: "For a corporation to become truly sustainable, it has to address two more cases of sustainable development. First, managers must consider the "natural case" for corporate sustainability: if a firm is operating close to (or even beyond) the environment's carrying capacity, it can never become truly sustainable. Second, firms also need to make the "societal case" for sustainability" (Dyllick \& Hockerts, 2002).

This emphasis on personal values suggests that there are missing the point with their identify cation of a "political bottom line" for corporate sustainable development, as are presented in $(\mathrm{Ba}-$ den-Fuller \& Mangematin, 2013; Schaltegger et al., 2006). Schaltegger and Burritt in 2006 write "the importance of tasks for applied research, development and training, including to conceptualize an acceptable proportionality dynamic in sustainability challenges to business and to independently research links between this proportionality and the mind sets, actions, attitudes and behaviors of managers, given the predetermined policy goal of a sustainable society".

Tourism is an uncertain industry, and, in many cases, it has been exposed as the giant with feet of clay that it really is, as its evolution remains 
very sensitive to sudden/violent changes in the tourism environment. Changes in the macro and/or micro environment in the form of political instability, revolution and terrorism can greatly dictate the future of tourist destinations and their viability.

The aim of this research study is forwarded for analysis of some decision support methods for more effective management of business in the abnormal conditions of transformations (in country and influence of international business enterprises). Tourism became quite complex, and dynamic business, and belongs for type of kind of international business. Our tasks are forwarded for provision of the more suitable infrastructure for sustainable management of tourism business according to the risk evaluation. And more attention will be played for tourism sector as case study of business in Egypt.

Our results shows the risk evaluation and efforts for provision of management of business enterprises by requirements of sustainable development. Some data illustrate the situation of local and global business in the area of management transformations in tourism sector on impacts of political changes in Egypt.

\section{Related works in the area of developing of risk management tools}

By analysing the types of risks we found some important issues provided by authors (E. Vaughan \& T. Vaughan, 2008) about the detailed picture of risk. Some instruments are dectribed in their book for lessening the size of the risks and containing them for subject to relentless establishments and devices that are figured with a reliable and target structure that encapsulates the control or dodging of dangers and diminishes their sufficiency to such an extent that prompts diminishing hardships to their base levels. The board instruments of risk management can be turned around in the plausibility of the development business work (E. Vaughan \& T. Vaughan, 2008). Risk control can be implementing by application of some management means. There are analyzed some means that can help to minimize the risk. This occurs by controlling the dangers when taking fitting measures to forestall the risk:

- Safety measures to guarantee passage and exit of vacationers from the visitor zones;

- Ensuring the adequacy of wellbeing and safety efforts in the visitor territories;

- Reducing impediments that forestall control of the risks that happen;
- Determine the zones that voyagers can visit, demonstrating potential risks.

How to avoid the risk? In literature we can found some proposals in this area. It is conceivable to keep away from the risks that travel industry organizations can confront while expanding their deals and control a huge piece of the overall industry in the serious business showcases (Walsh \& Taylor, 2007).

By following different techniques that can provoke authentic results explained by (Heath \& O'Hair, 2009):

- Ethical basic leadership that keeps risk from being found;

- Benefit from past encounters and nonrepeat that prompts misfortunes;

- Commitment to the standard details to create vacationer merchandise and ventures, making them liberated from deformities, and afterward the requirement for them or return to and living arrangement is rehashed.

How to make the risk re-education in tourism sector? Lessening risk relies upon methods that decrease the probability of misfortune or misfortune in the accompanying zones:

- Learn about the potential risks that can cause potential risks;

- Differentiate between visitor bunches whose presence together can cause clashes and wrestling episodes because of ethnic, partisan, strict, or social contrasts;

- Defining traveler bunches with the size and nature of dangers that they can look in the travel industry exercises and exercises, regardless of whether the ecological, social or political risks.

Indications of moving the risk starting with one condition then onto the next seem to stay away from misfortune or misfortune, through a few of the most significant angles, provided by (Fitzgerald, 2003):

- Contracting with insurance agencies to get remuneration when a potential or inactive risk happens in traveler regions, for example, fire and vandalism;

- Surrounding hazard zones and stores, embracing approaches and receiving explicit procedures to contain and isolate dangers and afterward the probability of moving them to somewhere else and decreasing it.

For example, what occurs in redirecting vacationer transport ways or spots of their appearance or takeoff, and necessitates that the risk move be recognized by the accompanying: 
- Transparency of the risk move process;

- Control of subjective information;

- Critical information investigation.

Risk sharing may happen and it is a strategy for managing threat. Right now, following danger is moved:

- the joining of traveler foundations in the inn or visitor anchors framework to share or take an interest in bearing the risks and misfortunes that the travel industry association may confront;

- merging with different organizations and their association under a brought together motto to spread the risks to other people;

- maintaining a venture portfolio from which the portions of the travel industry associations are disseminated, in a few undertakings that have created or future goals.

At the point when the circumstance is inadequate, incorrect, or surveyed, or on the off chance that it isn't transmitted in an auspicious way to the leader, in any case, the appearance of the significant data at the proper time gives a genuine chance to stay away from the peril as far as amount and quality during the time of confronting the threat (Röhn et al., 2015). Right now indicators show up plainly during the time spent air and sea route since you give important data about climate or climatic conditions in a successive way, and here it is important to give devices that help to maintain a strategic distance from dangers in traveler territories:

- Determine the exceptional territories that guests can enter to guarantee their security and shield them from hurt in rehearsing visitor exercises, for example, water skiing, wild the travel industry or plunging swimming.

- Planning for earnest cases that can occur, which requires the nearness of emergency treatment, with direct understanding to do medical aid, for example, suffocating cases on vacationer coasts.

- Provide exhortation to visitors to wear sportswear fitting for vacationer exercises while rehearsing traveler exercises.

The progression of significant data is an assistant factor in relation to the necessities of reacting to the risk prerequisites, and if there are repercussions for the expansion and development of risks in the encompassing condition, the issue of the nearness of an authority or chief of hazard in the hierarchical guide of visitor associations gives a particular spot and it ought to accomplish its place in the authoritative structure, as far as stream and coherence (World Economic Forum, 2013).

\section{A case study of assesment of the situations of risk in tourim business in Egypt during the past decade}

Tourism in Egypt has a long history and have very important impact to the development of economy of the country (Dziadosz, 2009). People are still fascinated to see places such as the Valley of the Kings and the many and various temples and architecture that Egypt has to offer, in addition to the trips to the pyramids, down the Nile, and the visit to Cairo's many museums. For decades, Egypt was the main draw for international tourists visiting North Africa. But the country's tourism industry has suffered a critical blow following a string of political misfortunes, a major airline disaster, terrorist attacks, and church bombings. Followinng some sources (Farouk, 2014), we can review, that the failed revolution of 2011 and the military's violent reassertion of power dampened growth in the sector, sent tourists packing, and turned luxury resorts into abandoned "ghost hotels". By public reports provided information constate what the situation was "exacerbated in 2015 after the Islamic State took responsibility for downing a Russian airliner over Sinai, killing all 224 people - most of them tourists - on board. Terrorism during some political events had importat influence for tourism sector. Deadly attacks on churches in the bustling seaport of Alexandria and the city of Tanta also put a dent on Egypt's image as a favorite tourist destination Egypt's ancient sites, museums, and parks have also experienced trouble, with several of them looted, deserted and artifacts stolen. The bombing also damaged the fasades and exhibits of the museums during the 2014 year destructional events, by forcing them for closing and renovations belonging for up to two years".

Some places (for example, Aquarium Grotto Garden in Cairo) are now empty. All these negative trends have coalesced to harm tourism, significantly reducing international flight bookings to Egypt, and pushing visitors. The low number of inbound tourists has also affected the economy, which looks to the sector as a crucial source of hard currency. To augment this and to secure funding for research and restoration activities, the government increased ticket prices to enter these parks and museums. Egypt's government also received a three-year, \$12 billion loan from the International Monetary Fund and devalued its currency by al- 
most half against the dollars in order to combat the severe economic crisis.

We can asses few most important problems in the tourism sector of Egypth:

- The loss of the sector by more than twothirds of the number of workers compared to a year ago.

- The low prices of the services provided in the hotels;

- The closure of tourism offices in other countries at a time when the demand from these countries for Egyptian tourism will be increasing.

- The tourism companies need for restructure, replacements and renovation.

- The internal transport in the tourist transport sector due to the high price.

\section{Possibilities of implementation of Action plans for risk management}

The concept of unsustainable development is related with risk evaluation in various political, economical, enviromnetal, social areas (Management Sustainable Development, 2019; Mensah \& Casadevall, 2019). Unsuspecting events influence business development as well. Risk management process relates with complexity and has many evaluation and management problems. It is important to understand this phenomenon by point of view of quite good evaluation techniques and auditable process that guides unsustainability-related risk evaluation, assessment, and management by providing the best possibilities (George \& Bock, 2011). We follow by some recommendations for integration of some means, for example, as developing of the risk registers and some activities implementation into the operating plans by supporting the means for successful operative implementation in actions. The development of information and communications technology (ICT) have influence for adequate development of e-services for tourism sector (Dzemydienè et al., 2015, 2016). As part of this evaluation process, the issues of exploration, production and major projects have to be examined against the physical, social and political settings of operations. Local concerns may influence the potential importance of these environmental and stakeholder matters including long-term risks and cumulative impacts. Examples of these concerns are water management and land-use agreements with indigenous peoples. It is possible to assess the types of risk by identification of some diverse groups of subject matter experts in each business unit (BU) and implementing projects.
We can use the matrix for evaluation of risk type, by implementing the plotting on a matrix mechanism for the evaluation both its likelihood and consequence. In evaluating the consequence level, we consider potential environmental and social risks, such as socio-cultural and economic impacts to stakeholders, environmental impact, and reputational and financial implications. Time horizons considered are short-term (zero to five years), mid-term (five to 10 years) and long-term (10-25 years). The criteria for priority of factors provision of risks can included in the some tools, for examples as the Risk Registers of Corporates. As part of the assesment process, the interdependences between the risks and work to identify emerging risks are evaluated. Such means can be implementing as regulatory requirements.

The risk management process have to ensure the Action Plans for development of track mitigation activities for each type of risk including in the analyzing area. Some of authors would like to propose to develop the Risk Register (Bloomberg, 2017; Birkin, 2007). The plans have to include many compex means and to analyse the ommitments, related responsibilities, resources and milestones more in details. As part of regular updates to the register, the action plans and their effectiveness are evaluated, and decisions are made to continue mitigation measures, add new measures, or simply monitor the risk for further developments. The Risk Register and action plans are recommending for usage to ensure the track performance and guide goal setting.

Action plans for prioritized risks are typically managed at the business unit (BU) level, along with the ongoing management by requirements of sustainable development (SD) performance and engagement designed to minimize or avoid other social and environmental aspects of the business. Overarching risk management actions, such as GHG target setting, prioritization of global emissions-abatement projects and disclosure and reporting, are managed at the corporate level.

The risk of unsustainability have to be integrated into strategy through the risk management process into the analysed Corporate or Enterprise Risk Management (ERM) system, by recommendations of (ConocoPhilips, 2018). They recommend "to assess risks from the corporate SD Risk Register, that is mapped to relevant enterprise risks including market, reputational, operational and political risks. The auditing and reporting about such activities to the such type committies of the country can be proposed as the influencing mean helping for enterprise risks evaluation". We 
have some examples of working of the Audit and Finance Committees (AFC), which receives the annual updates on how enterprise risk is being addressed, mitigated and managed across the company.

\section{Evaluation of situation in the area of man- agement transformations in tourism sector on impacts of political changes in Egypt}

Tourism is one of the leading sources of income, crucial to Egypt's economy (Dahir, 2017). The evaluation of tourim situation by statistical data can show the picture during the time period from 2007 until 2018 years (Figure 1, Figure 2). Such tourim sector has peak in 2010, and employed about $12 \%$ of Egypt's workforce (Alexander, October 20, 2009). Serving approximately 14.7 million visitors Egypt, and providing revenues of nearly $\$ 12.5$ billion (Adela Ragab, January $14-15$, 2014). As well as contributing more than $11 \%$ of Gross Domestic Product (GDP) and $14.4 \%$ of foreign currency revenues (Matt Smith, 11 September, 2014).

During the Egyptian Revolution of 2011, the number of visitors plummeted by over $37 \%$ that year falling from 14 million in 2010 to 9 million by the end of 2011. This has impacted a diverse range of businesses directly or indirectly dependent on tourism, from travel accommodation and tourist attractions to car rental and air transportation, as well as health and wellness industries. Tour operators offering heavy discounts to encourage tourists back have been somewhat successful at the Red Sea resorts where prices remain lower compared to 2011.

In the first half of 2014 the number of tourists further declined by $25 \%$ as compared with the same period of 2013, while revenues shrank by $25 \%$ as well (Dalia Farouk, 16 July 2014) (Figure 2). In 2013, Egypt ranked 85th as the world's best country in terms of tourism and traveling, falling ten places from its ranking of 75 in 2011. However, it regained some ground in the 2017 rankings being rated 75 th overall by data of (World Economic Forum, 2013).

This research explores the need to establish new sustainable business models in Egypt and uses multiple objectives to develop the Egyptian companies the reality of the level of sustainable development, environmental awareness and performance, community responsibility, performance barriers and drivers and other sustainability issues.

The environmental awareness, community responsibility, performance barriers and drivers and other sustainability issues have to examine by using of multiple objectives. Some important factors of influencing changes in tourism sector are presented in (Table 1). There are some companies refers to the lack of significant sustainable development practices in Egypt. The samples of Egyptian companies illustrate the situation of local and global business in the area of management transformations in tourism sector on impacts of political changes in Egypt.

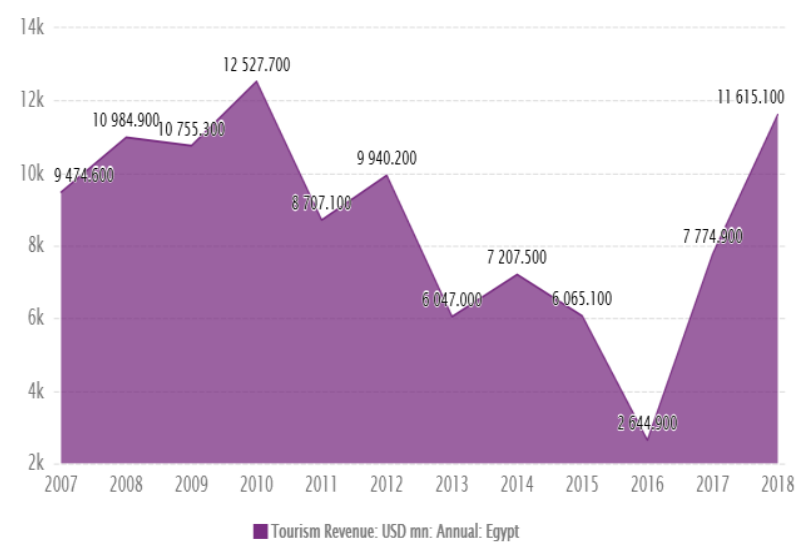

Figure 1. Tourism in Egypt and revenue during 20072018 years period (source: CEIC Data, 2019a)

The latest United Nations World Tourism Organization (UNWTO) has revealed that Egypt is one of the world's fast-growing tourist destination for 2017 , it raised to 8 million compared to last year which was about 5.26 million (Haines, 2017) surprising destinations where tourism is booming in 2017 (Figure 2).

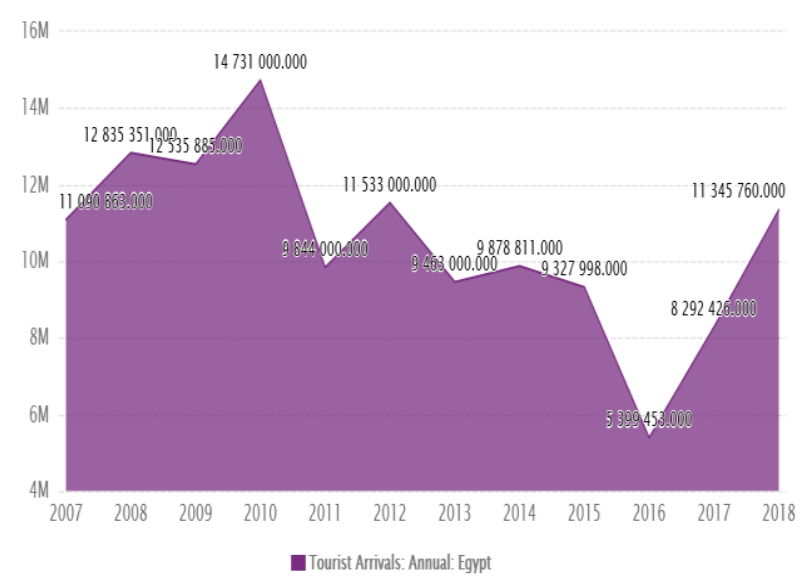

Figure 2. Illustration of dynamics of arrivals of visitors in Egypth during the 2007-2018 years period (source: CEIC Data, 2019b)

Media monitoring can help to identify and describe the reflection in selected mass media for sustainable development. 
Table 1. Evaluation of some parameters of the Egyptian economy before and after the revolution

\begin{tabular}{|l|l|c|c|c|c|}
\hline \multicolumn{1}{|c|}{ Criteria } & \multicolumn{1}{c|}{$\begin{array}{c}\text { Measurement } \\
\text { units }\end{array}$} & $2009-2010$ & $2011-2012$ & $2012-2013$ & $2016-2017$ \\
\hline $\begin{array}{l}\text { Growth rate for } \\
\text { economy }\end{array}$ & $\%$ & 5.1 & 2.2 & 2.1 & 5.2 \\
\hline Interest rate & $\%$ & 9.75 & 9.75 & 10.75 & 18.75 \\
\hline Exchange rate & P/\$ & 5.7 & 6.06 & 7.0 & 17.88 \\
\hline Cash reserve & $\begin{array}{l}\text { Pillion Egyptian } \\
\text { Pounds }\end{array}$ & 35.2 & 15.5 & 251.1 & 44.3 \\
\hline Tax proceeds & $\begin{array}{l}\text { Pillion Egyptian } \\
\text { Pounds }\end{array}$ & 170.5 & 207.4 & 239.7 & 624.0 \\
\hline Budget deficit & $\begin{array}{l}\text { Pillion Egyptian } \\
\text { Pounds }\end{array}$ & 98.0 & 166.7 & 1527.4 & $\begin{array}{l}3694.9 \text { Million } \\
\text { Egyptian Pounds }\end{array}$ \\
\hline Local debt & $\begin{array}{l}\text { Pillion Egyptian } \\
\text { Pounds }\end{array}$ & 888.7 & 1238.1 & 43.2 & 92.6 \\
\hline External debt & $\begin{array}{l}\text { Pillion Egyptian } \\
\text { Pounds }\end{array}$ & 33.7 & 34.4 & 203.1 & $\begin{array}{l}437.4 \text { Million } \\
\text { Egyptian Pounds }\end{array}$ \\
\hline $\begin{array}{l}\text { Interest local } \\
\text { debt }\end{array}$ & $\begin{array}{l}\text { Pillion Egyptian } \\
\text { Pounds }\end{array}$ & 72.3 & 104.2 & & 252.7 \\
\hline
\end{tabular}

Some economical parameters are shown in Table 1, by the official statistical data and the annual reports of enterprises.

Although small and medium sized companies appeared to show interest in tourism area and would like to further contribute to for example triple bottom line objectives. Increasing concerns are found from the company level regarding the need to use renewable energy, source alternative sustainable materials, improve the quality of products produced rather than reducing cost, export to Europe and treat employees as an asset. The lack of skills, finance and knowledge are found to be prohibiting the effective embedment of sustainable development within companies and hence cause an under-performance in this regard. The study concludes that the establishing of a new business model for sustainable development in Egypt.

\section{Conclusions}

The risk factors are described in this research by pointing the unsustainable development of many influences. The sustainability is reflected in the level of environmental commitment in tourism sector in Egypt, and this area particularly along the ecologically sensitive. Red Sea coast where a high level of environmental consideration is necessary for environmentally sustainable tourism development.

These findings suggest that Egypt should focus on improving the quality rather than increasing the quantity of tourism. Accordingly, the marketing competitive advantage should be the quality and uniqueness of the destination rather than its low price. In terms of private-public sector interactions, governmental institutions should assume a more active role in environmental protection and should employ experts and knowledgeable professionals as decision makers, while the private sector should be encouraged to undertake large-scale tourism projects. It is found that sustainable tourism cannot be achieved without the contribution and collaboration of both parties in tourism planning and development there is evidence that Egypt, represented by the president and government, intends to use business to meet social and environmental objectives as well as economic, and in doing so Egyptian business models will have to accommodate a very significant government influence. The extent to which such business models are mainly free-market or government policy derivatives remain to be seen.

\section{References}

Baden-Fuller, C., \& Mangematin, V. (2013). Business models: A challenging agenda. Strategic Organization, 11(4), 418-427. https://doi.org/10.1177/1476127013510112

Birkin, F. (2007). New sustainable business models in China. Wiley Inter Science. http://www.greenprof.org/wpcontent/uploads/2010/04/New-SustainableBusiness-Models-in-China.pdf

Bloomberg. (2017). Where to go in 2017. https://www.bloomberg.com/news/features/201701-04/where-to-go-in-2017 
CEIC Data. (2019a). Egypt tourism revenue.

https://www.ceicdata.com/en/indicator/egypt/tourismrevenue

CEIC Data. (2019b). Egypt visitor arrivals. https://www.ceicdata.com/en/indicator/egypt/visito r-arrivals

ConocoPhillips. (2018). Managing sustainable development risks (Official report).

http://www.conocophillips.com/sustainability/integ rating-sustainability/managing-sustainable-

development-risks/

Dahir, A. L. (2017). Egypt is trying to get the tourists back to see the pyramids after years of security fears.

https://qz.com/africa/1077425/egypts-tourismlooks-to-revive-after-years-of-sluggish-growth/

Dyllick, T., \& Hockerts, K. (2002). Beyond the business case for corporate sustainability. Business Strategy and Environment, 11(2), 130-141. https://doi.org/10.1002/bse.323

Dzemydienè, D., Maskeliūnas, S., Dzemydaitè, G., \& Miliauskas, A. (2016). Semi-automatic service provision based on interaction of data warehouses for evaluation of water resources. Informatica, 27(4), 709-722.

https://doi.org/10.15388/Informatica.2016.107

Dzemydiene, D., Maskeliūnas, S., Miliauskas, A., Naujikienè, R., \& Dzemydaitè, G. (2015). E-service composition for decision support, based on monitoring of contamination processes and analysis of water resource data. Technological and Economic Development of Economy, 21(6), 869-884. https://doi.org/10.3846/20294913.2015.1069417

Dziadosz, A. (2009). Reuters Africa. Egypt tourism numbers to fall less than feared.

https://af.reuters.com/article/investingNews/idAFJ OE59J0PG20091020?sp=true

Farouk, D. (2014). Egypt tourist numbers decline 20.5 pct in June year-on-year. AhramOnline.

http://english.ahram.org.eg/NewsContent/3/12/106 415/Business/Economy/Egypt-tourist-numbersdecline--pct-in-June-yearony.aspx

Fitzgerald, P. (2003). Canadian tourism commission: Risk management guide for tourism operators. http://213.168.31.139/webfiles/DVD/mod\%203/en /risk\%20analysis\%20canada.pdf

George, G., \& Bock, A. J. (2011). The business model in practice and its implications for entrepreneurship research. Entrepreneurship Theory and Practice, 35(1), 83-111. https://doi.org/10.1111/j.1540-6520.2010.00424.x

Haines, G. (2017). Telegraph. 10 surprising destinations where tourism is booming in 2017. https://www.telegraph.co.uk/travel/news/surprising -countries-where-tourism-is-booming-in-2017/
Heath, H. D., \& O’Hair, H. D. (Eds.). (2009). Handbook of risk and crisis communication (pp. 576-590). Routledge.

Management Sustainable Development. (2019). Conoco Phillips.

http://www.conocophillips.com/sustainability/integ rating-sustainability/managing-sustainabledevelopment-risks/

Mensah, J., \& Casadevall, S. R. (2019). Sustainable development: Meaning, history, principles, pillars, and implications for human action: Literature review. Cogent Social Sciences, 5(1), 1-21. https://doi.org/10.1080/23311886.2019.1653531

Ragab, A. (2014). Fourteenth meeting of the committee of statistics and Tourism Satellite Account (TSA). http://cf.cdn.unwto.org/sites/all/files/pdf/14th_mee ting_egypt.pdf

Röhn, O., Caldera Sánchez, A., Hermansen, M., \& Rasmussen, M. (2015). Economic resilience: A new set of vulnerability indicators for OECD countries (Economics department working papers No. 1249).

http://www.oecd.org/officialdocuments/publicdispl aydocumentpdf/?cote $=\mathrm{ECO} / \mathrm{WKP}(2015) 67 \&$ docLanguage $=$ En

Schaltegger, S., Bennett, M., \& Burritt, R. (2006). Sustainability accounting and reporting: Development, linkages and reflection. An introduction. In Sustainability accounting and reporting (pp. 1-33). Springer, Dordrecht. https://doi.org/10.1007/978-1-4020-4974-3_1

Smith, M. (2014). Egypt tourist numbers to rise 5-10 pct in 2014 - minister. Reuters. https://www.reuters.com/article/egypttourism/egypt-tourist-numbers-to-rise-5-10-pct-in2014-minister-idUSL5N0RC3CF20140911

Transforming our world: The 2030 agenda for sustainable development. (2015). Resolution adopted by the General Assembly on 25 September 2015, p. 1-35. https://www.un.org/ga/search/view_doc.asp?symb $\mathrm{ol}=\mathrm{A} / \mathrm{RES} / 70 / 1 \&$ Lang $=\mathrm{E}$

Vaughan, E. J., \& Vaughan, T. M. (2008). Fundamentals of risk and insurance $\left(10^{\text {th }}\right.$ ed.). John Wiley \& Sons.

Walsh, K., \& Taylor, M. S. (2007). Developing inhouse careers and retaining management talent: What hospitality professionals want from their jobs [Electronic version]. Cornell Hotel and Restaurant Administration Quarterly, 48(2), 163-182. https://doi.org/10.1177/0010880407300521

World Economic Forum. (2013). The travel \& tourism competitiveness report 2013. http://www3.weforum.org/docs/TTCR/2013/TTCR _OverallRankings_2013.pdf 